\title{
Ochrona przed stresem oksydacyjnym w męskim układzie płciowym
}

\section{Protection against oxidative stress in male reproductive system}

\author{
Mariola Marchlewicz', Dagmara Szypulska-Koziarska², Adam Grzegrzółka², Joanna Kruk², Ewa Duchnik, \\ Barbara Wiszniewska²
}

${ }^{1}$ Zakład Dermatologii Estetycznej Pomorskiego Uniwersytetu Medycznego w Szczecinie
al. Powstańców Wlkp. 72, 70-111 Szczecin

Kierownik: prof. dr hab. n. med. Mariola Marchlewicz

${ }^{2}$ Katedra i Zakład Histologii i Embriologii Pomorskiego Uniwersytetu Medycznego w Szczecinie

al. Powstańców Wlkp. 72, 70-111 Szczecin

Kierownik: prof. dr hab. n. med. Barbara Wiszniewska

${ }^{3}$ Zakład Profilaktyki i Terapii Zajęciowej Wydziału Kultury Fizycznej i Promocji Zdrowia Uniwersytetu Szczecińskiego

al. Piastów 40b/6, 71-065 Szczecin

Kierownik: dr hab., prof. US Joanna Kruk

${ }^{4}$ Klinika Chorób Skórnych i Wenerycznych Pomorskiego Uniwersytetu Medycznego w Szczecinie

ul. Siedlecka 2, 72-010 Police

Kierownik: prof. dr hab. n. med. Romuald Maleszka

\begin{abstract}
Reactive oxygen species (ROS) play in the male reproductive system important physiological functions in cell signaling, spermatogenesis and sperm maturation in epididymis. The influence of various factors, e.g. environmental, could be the reason for oxidative stress. This can lead to the exposure of cells to the toxic effects of many oxidants such as $\mathrm{O}^{-}{ }_{2}, \mathrm{O}_{3}, \mathrm{H}_{2} \mathrm{O}_{2},{ }^{\circ} \mathrm{OH}$. The source of ROS may be spermatozoa, which also, due to the composition of the cytoplasmic membrane lipids and great amount
\end{abstract}

of mitochondria are particularly susceptible to oxidative damage. Oxidative stress can damage their membranes, DNA, inhibit sperm motility and reduce their fertilization ability. This dual effect of ROS confirms the unique role of antioxidant enzymes (such as SOD, CAT and GPX) and non-enzymatic (e.g. GSH, vitamins A, E, C, transferrin) responsible for maintaining adequate levels of ROS in the male reproductive system.

Keywords: antioxidants, reactive oxygen species, testis, epididymis, spermatozoa.

\section{STRESZCZENIE}

Reaktywne formy tlenu (RFT) pełnią w męskim układzie płciowym ważne funkcje fizjologiczne, m.in. w sygnalizacji komórkowej, w procesach spermatogenezy oraz najądrzowego dojrzewania plemników. Pod wpływem różnych czynników, np. środowiskowych, dochodzić może do zaburzenia równowagi oksydoredukcyjnej, czyli stresu oksydacyjnego. Prowadzi to do ekspozycji komórek na toksyczne działanie wielu utleniaczy, takich jak: $\mathrm{O}^{\circ-}{ }_{2}, \mathrm{O}_{3}, \mathrm{H}_{2} \mathrm{O}_{2},{ }^{\circ} \mathrm{OH}$. Źródłem RFT mogą być plemniki, które jednocześnie ze względu na skład błon cytoplazmatycznych oraz dużą zawartość mitochondriów są wyjątkowo podatne na uszkodzenia peroksydacyjne. Stres oksydacyjny może uszkadzać ich błony i zawarty w nich DNA, hamować ruchliwość plemników oraz zmniejszać ich zdolność do zapłodnienia. Ten podwójny efekt działania RFT potwierdza szczególną rolę antyoksydantów enzymatycznych (m.in. SOD, CAT, GPX) i nieenzymatycznych (m.in. GSH, witaminy A, E, C, transferyny) odpowiedzialnych za utrzymanie odpowiedniego stężenia RFT w męskim układzie płciowym.

Słowa kluczowe: antyoksydanty, reaktywne formy tlenu, jądro, najądrze, plemniki.

\section{WSTĘP}

Problem niepłodności partnerskiej jest obecnie niezwykle aktualny i dotyczy 15-20\% par. Uważa się, że czynnik męski odpowiada za 50-60\% przypadków [1]. Zaburzenia płodności mogą mieć wiele przyczyn, m.in. choroby narządów płciowych, choroby ogólnoustrojowe oraz długotrwały stres o dużym nasileniu [2], palenie papierosów, spożywanie znacznej ilości alkoholu, otyłość, zanieczyszczenie środowiska, stres oksydacyjny [3]. W ostatnim 20-leciu prowadzone były intensywne badania interakcji reaktywnych form tleny (RFT) z plemnikami. Wiadomo, że RFT wywierają zarówno pozytywny, jak i negatywny wpływ na komórki, w tym plemniki [3]. Niewielkie stężenia RFT pełnią istotną rolę zarówno w procesie spermatogenezy, jak i w funkcjach fizjologicznych męskich gamet [4]. Wykazano, że plemniki mają własne wyposażenie generujące RFT [5], a procesy takie jak stymulacja kapacytacji, hiperaktywacja, reakcja akrosomowa oraz interakcja plemnika z komórką jajową stymulowane są wzrostem stężenia cyklicznego adenozynomonofosforanu, anionorodnika ponadtlenkowego $\left(\mathrm{O}^{--}\right)$ 
oraz nadtlenku wodoru $\left(\mathrm{H}_{2} \mathrm{O}_{2}\right)$. Działają one m.in. jako drugie informatory w procesie fosforylacji tyrozyny $[4,6,7,8,9,10,11]$. Jednak w przypadku stresu tlenowego zbyt wysokie stężenie RFT może uszkadzać błony plemników i DNA [9, 10, 11, 12, 13, 14, 15], hamować ruchliwość, a także zmniejszać ich zdolność do zapłodnienia [16]. Ten podwójny efekt działania RFT potwierdza szczególną rolę zarówno antyoksydantów nieenzymatycznych, jak i enzymów antyoksydacyjnych ulegających ekspresji w męskim układzie płciowym $[7,17]$.

\section{REAKTYWNE FORMY TLENU}

Reaktywne formy tlenu nie tylko pełnią ważne fizjologiczne funkcje w organizmie, ale mogą być również bardzo toksyczne z uwagi na wielką chemiczną reaktywność [16]. Są one produktami metabolizmu tlenu cząsteczkowego, którego stan podstawowy jest stanem trypletowym $\left({ }^{3} \mathrm{O}_{2}\right)$. Stan trypletowy cząsteczki tlenu ogranicza szybkość jego reakcji na drodze dwuelektronowej, dlatego molekuła ta jest słabym utleniaczem, reaguje jednak z wieloma związkami, przyjmując od nich jeden elektron. Anionorodnik ponadtlenkowy $\left(\mathrm{O}^{-{ }^{-}}\right)$powstaje w komórkach ludzkich głównie w mitochondriach. Szacuje się, że ok. 1-5\% tlenu zużywanego przez mitochondria ulega jednoelektronowej redukcji do $\mathrm{O}^{\bullet-}{ }_{2} \mathrm{~W}$ mitochondrialnym łańcuchu oddechowym $[16,18]$. Redukcja ${ }^{3} \mathrm{O}_{2}$ do $0^{\circ-}{ }_{2}$ jest również wywoływana przez enzymy oksydazy fosforanu dwunukleotydu nikotynamidoadeninowego i oksydazę ksantynową [16]. Anionorodnik ponadtlenkowy posiada własności zarówno utleniające, jak i redukujące. Charakteryzuje go duża reaktywność wobec związków zawierających grupy tiolowe (-SH), reaguje też ze związkami redukującymi, jak askorbinian czy dinukleotyd nikotynamidoadeninowy. Wykazuje szczególnie dużą reaktywność wobec jonów metali o zmiennej wartościowości, które redukuje (np. jony $\mathrm{Fe}^{+3}$ do $\mathrm{Fe}^{+2}$ ). Sprotonowana forma $\mathrm{O}^{--}$, czyli rodnik ponadtlenkowy $\left(\mathrm{HO}_{2}^{\circ}\right)$, może inicjować reakcję peroksydacji lipidów [4].

Produktem dwuelektronowej redukcji ${ }^{3} \mathrm{O}_{2}$ jest rodnik hydroksylowy ( $\left.{ }^{\circ} \mathrm{OH}\right)$, który uważany jest za jeden z najsilniejszych utleniaczy - reaguje z pierwszą napotkaną cząsteczką w miejscu swojego powstawania, z szybkością kontrolowaną jedynie przez dyfuzję. W układach biologicznych ${ }^{\circ} \mathrm{OH}$ powstaje w reakcji Fentona:

$$
\mathrm{Fe}^{+2}+\mathrm{H}_{2} \mathrm{O}_{2} \rightarrow \mathrm{Fe}^{+3}+\mathrm{OH}^{-}+{ }^{\cdot} \mathrm{OH}
$$

Utlenione w powyższej reakcji jony żelaza są redukowane przez $\mathrm{O}^{--}{ }_{2}$ :

$$
\mathrm{Fe}^{+3}+\mathrm{O}^{\circ-} \rightarrow \mathrm{Fe}^{+2}+\mathrm{O}_{2}
$$

Reakcja (1) może być katalizowana przez inne jony ulegające reakcjom redoks, jak jony miedzi, niklu, kobaltu, chromu, manganu, szczególnie w przypadku gdy są skompleksowane z chelatorami [19]. Większość badaczy uważa, że wystarcza obecność śladowych stężeń metali, by powyższe reakcje mogły zajść. Suma reakcji (1) i (2) daje reakcję znaną jako reakcja Habera-Weissa. Reakcja ta zachodzi między $\mathrm{O}_{2}{ }_{2} \mathrm{i}_{2} \mathrm{O}_{2}$, a jony żelaza pełnią rolę katalizatora.

$$
\mathrm{O}^{\circ-}{ }_{2}+\mathrm{H}_{2} \mathrm{O}_{2} \rightarrow \cdot \mathrm{OH}+\mathrm{OH}^{-}+\mathrm{O}_{2}
$$

Reakcje Fentona i Habera-Weissa zachodzą z udziałem $\mathrm{O}^{{ }^{--}} 2$ oraz/lub $\mathrm{H}_{2} \mathrm{O}_{2}$. Powstający ${ }^{\circ} \mathrm{OH}$ jest inicjatorem reakcji utleniania lipidów, bowiem znany jest z odrywania atomu wodoru od alkanów i ich pochodnych. Z łatwością przyłącza się również do podwójnych wiązań w cząsteczkach [4, 16].

$\mathrm{Z}$ kolei $\mathrm{H}_{2} \mathrm{O}_{2}$ jest produktem trójelektronowej redukcji ${ }^{3} \mathrm{O}_{2}$. W peroksysomach $\mathrm{H}_{2} \mathrm{O}_{2}$ jest generowany przez oksydazy uczestniczące w $\beta$-oksydacji kwasów tłuszczowych i w cyklu glioksalowym oraz przez układ ksantyna-oksydaza ksantynowa lub przez oksydazę moczanową. Nadtlenek wodoru powstaje też jako produkt spontanicznej dysmutacji dwóch rodników $\mathrm{O}^{\circ-}$; reakcja ta jest katalizowana przez dysmutazę ponadtlenkową (SOD) $[4,16,20]$. Cząsteczka $\mathrm{H}_{2} \mathrm{O}_{2}$ jako obojętna elektrycznie może z łatwością przenikać do wnętrza komórki i wywoływać tam uszkodzenia. Istotne są trzy rodzaje reakcji, w których uczestniczy $\mathrm{H}_{2} \mathrm{O}_{2}$ : utlenianie składników komórki zawierających grupy tiolowe, udział w reakcji Fentona (reakcja 1) oraz reakcja dysproporcjonowania (reakcja 4) [4, 21].

$2 \mathrm{H}_{2} \mathrm{O}_{2} \rightarrow 2 \mathrm{H}_{2} \mathrm{O}+\mathrm{O}_{2}$

Pewna ilość tlenu uwolnionego w reakcji (4) może być elektronowo wzbudzona. Ta forma tlenu jest tlenem singletowym $\left({ }^{1} \mathrm{O}_{2}\right)$. Reaguje bardzo łatwo ze związkami w stanie singletowym.Źródłem ${ }^{1} \mathrm{O}_{2}$ jest wiele reakcji enzymatycznych, np. utlenianie ksantyny w obecności oksydazy ksantynowej, NADPH w obecności cy tochromu c i reduktazy adrenodoksyny oraz cyklooksygenazy [4, 22]. Ta aktywna forma tlenu może być również generowana w komórce w wyniku wielu reakcji nieenzymatycznych, jak rozpad nadtlenków organicznych, nadtlenku wodoru czy peroksydacji lipidów.

\section{KONSEKWENCJE STRESU OKSYDACYJNEGO}

Jeśli stan równowagi między szybkością generowania RFT w komórce a ich unieszkodliwianiem ulega zaburzeniu i występuje niekontrolowany wzrost ich stężenia oraz niewystarczająca jest wydajność mechanizmów naprawiających szkody wyrządzone przez RFT, oznacza to wystąpienie stresu oksydacyjnego [4], którego skutki dla komórek są szeroko dyskutowane $[4,7,23,24,25,26,27]$. Konsekwencje stresu oksydacyjnego są różnorodne, należą do nich peroksydacja lipidów, utlenianie węglowodanów, uszkodzenia białek, błon komórkowych $[28,29]$ oraz kwasów nukleinowych [4]. Za uszkodzenia tych ostatnich odpowiedzialne są głównie ${ }^{\circ} \mathrm{OH} \mathrm{i}^{1} \mathrm{O}_{2}$ [4]. W plemnikach wymienione RFT zaburzają strukturę puryn i pirymidyn, deoksyrybozy w DNA, rybozy w RNA, rozrywają wiązania fosfodiestrowe między nukleotydami, powodują pękanie nici DNA oraz tworzenie adduktów [4, 21]. W konsekwencji mogą pojawić się zaburzenia procesów replikacji i transkrypcji, delecje, niestabilność genomu i rearanżacje chromosomów [4, 30]. Reakcja RFT z adeniną i guaniną skutkuje powstaniem dwuwartościowych 8-oksylowych związków pochodnych, z których powstają mutagenne zasady 8-hydroksylowe lub formamidopirymidyny. Ekspozycja cytozyny i tyminy na RFT prowadzi do powstania m.in. dihydrotyminy, 5-hydrocytozyny i 5-hydroksymetylouracylu [31]. Utlenione zasady azotowe są 
odpowiedzialne za powstawanie w DNA mutacji punktowych, które mogą zwiększać ekspresję protoonkogenów, a przez to zapoczątkowywać proces kancerogenezy [4]. Uszkodzenia DNA prowadzą do wzrostu aktywności polimerazy poli(ADP-rybozy), której substratem jest NAD ${ }^{+}$. Zwiększone zużycie $\mathrm{NAD}^{+}$ zmniejsza jego dostępną pulę, hamując proces glikolizy i cykl Krebsa [32]. Według Lanzafame i wsp. [30] fragmentacja DNA wydaje się być odwrotnie proporcjonalna do liczby plemników, ich morfologii, ruchliwości oraz zdolności do zapłodnienia [30]. Uszkodzenie DNA gamet męskich może być przyczyną występowania nowotworów u potomstwa [4]. Uważa się, że RFT oddziałują zarówno na mitochondrialny, jak i jądrowy DNA [27].

Szczególnie narażony na oksydacyjne uszkodzenia jest mitochondrialny DNA, ponieważ znajduje się w bliskim sąsiedztwie łańcucha oddechowego i tworzy kompleksy z białkami niehistonowymi, które nie zapewniają dostatecznej ochrony przed stresem oksydacyjnym. Dodatkowo mitochondria cechuje ograniczona zdolność naprawy DNA [31]. Stres oksydacyjny może powodować obniżenie stężenia ATP (adenozynotrifosforan) w komórce z wielu powodów: uszkodzenia mitochondriów, zwiększonego zużycia ATP, zmniejszenia podaży zredukowanych dinukleotydów nikotynoadeninowych wskutek zmniejszenia ich syntezy, przeciekania przez błonę komórkową, czy też zużycia do redukcji glutationu i naprawy DNA, wzmożonego katabolizmu nukleotydów adeninowych zarówno do aktywnego transportu utlenionego glutationu (GSSG) na zewnątrz komórki, jak i przez proteazy zależne od ATP oraz zahamowania glikolizy wskutek obniżenia aktywności dehydrogenazy gliceraldehydo-3-fosforanowej w wyniku utleniania grup sulfhydrylowych tego enzymu [22].

Za uszkodzenia białek odpowiedzialne są przede wszystkim: $\cdot \mathrm{OH}, \mathrm{H}_{2} \mathrm{O}_{2}, \mathrm{O}^{\cdot-}$. Modyfikują one zarówno grupy prostetyczne enzymów, jak i reszty aminokwasowe, powodując pękanie łańcuchów polipeptydowych, fragmentację białek oraz ich agregację. Szczególnie narażone na działanie RFT są aminokwasy: tyrozyna, tryptofan, cysteina i metionina [4]. Utlenienie grup -SH prowadzi do zaniku aktywności biologicznej białek. Wyjątkowo niebezpieczna jest oksydacja grup -SH w błonach komórkowych, ponieważ prowadzi do zwiększenia ich przepuszczalności i dezintegracji [4]. Zmodyfikowane białka wykazują tendencję do agregacji, a ponieważ nie podlegają ubikwitynizacji, nie są też rozpoznawane przez proteasomy, wobec tego nie są podatne na degradację [21].

Peroksydacja lipidów jest procesem kaskadowym, nieodłącznie związanym z metabolizmem organizmów aerobowych. Dotyczy głównie nienasyconych kwasów tłuszczowych będących podstawowym elementem błon komórkowych [4]. Proces utleniania lipidów obejmuje reakcje: inicjacji, propagacji i terminacji. W pierwszym etapie, pod wpływem rodnika hydroksylowego, nadtlenkowego, alkoksylowego lub alkilowego, atom wodoru jest odrywany od cząsteczki wielonienasyconego kwasu tłuszczowego lub jego reszty kwasowej. W czasie propagacji wolne rodniki alkilowe reagują z tlenem, tworząc wolne rodniki nadtlenkowe, które mogą odrywać atomy wodoru od następnych cząsteczek wielonienasyconych kwasów tłuszczowych [22]. Reakcja terminacji może zachodzić między dwoma rodnikami alkilowymi, nadtlenkowymi lub dwoma różnymi rodnikami. W konsekwencji w błonach komórkowych powstają m.in. dimery fosfolipidów, dialdehyd malonylowy, aldehydy i hydroksyaldehydy. Związki te, działające kancero- i mutagennie, modyfikują szybkość proliferacji komórki oraz właściwości fizyczne błon biologicznych, takie jak: różnica potencjałów, przepuszczalność dla jonów (np. dla wapnia), co szybko zaburza homeostazę wapniową w komórce [4, 22]. Utrzymanie homeostazy ustrojowej, w tym równowagi między tworzeniem RFT a ich dezaktywacją, zależy od obronnych mechanizmów komórki, zarówno tych enzymatycznych, jak i nieenzymatycznych [16, 25, 33, 34, 35].

Można wyróżnić trzy główne mechanizmy obrony przed RFT: 1) ochronę przed generowaniem produktów redukcji tlenu $\mathrm{i}^{1} \mathrm{O}_{2}$ przez usuwanie katalizatorów reakcji, w których one powstają; 2) zatrzymanie reakcji wolnorodnikowych i nierodnikowych, w których uczestniczą RFT, 3) usuwanie z komórki produktów reakcji RFT z makromolekułami oraz naprawa wywołanych przez nie uszkodzeń [22].

Z uwagi na podwójną funkcję RFT wobec plemników, szczególne znaczenie ma utrzymanie subtelnej równowagi między ich tworzeniem i rozkładem w świetle przewodu najądrza, dlatego w narządzie tym następuje ekspresja głównych enzymów (dysmutaza ponadtlenkowa, katalaza i peroksydaza glutationowa) chroniących komórki przed RFT oraz nieenzymatycznych „zmiataczy RFT” [17, 36, 37, 38, 39, 40]. Nie do końca poznana jest jednak efektywność mechanizmów antyoksydacyjnych najądrza w przypadku działania czynników wywołujących stres oksydacyjny. Wiadomo z kolei, że nasienie składa się z płynu nasiennego stanowiącego 90\% objętości i zawieszonych w nim plemników. Płyn nasienny, w zależności od gatunku, zawierać może także enzymy antyoksydacyjne uczestniczące w ochronie ejakulowanych plemników [5, 41]. Około 60-70\% plazmy nasienia stanowi wydzielina pęcherzyków nasiennych, pozostała część to wydzielina z gruczołu krokowego, jąder, najądrzy i gruczołów Cowpera. W skład plazmy nasienia wchodzą także: fruktoza, fosfolipidy, prostanglandyny, hialuronidaza i fibrynolizyna, a także karnityna, aminokwasy, witamina $\mathrm{C}$ oraz biopierwiastki ( $\mathrm{K}, \mathrm{Zn}, \mathrm{Na}, \mathrm{Mg}, \mathrm{Cu}, \mathrm{Ca}$, Fe). Cynk i żelazo uczestniczą w procesach utleniania i redukcji, z kolei cynk i magnez są stabilizatorami błon komórkowych. Cynk i miedź są koenzymami dysmutazy ponadtlenkowej zapobiegającej szkodliwemu działaniu wolnych rodników tlenowych na plemniki [42].

\section{DYSMUTAZY PONADTLENKOWE}

Dysmutazy ponadtlenkowe należą do rodziny metaloprotein, są enzymami przeprowadzającymi reakcje dysmutacji anionorodnika ponadtlenkowego do nadtlenku wodoru:

SOD $-\mathrm{Cu}^{+}+\mathrm{O}^{--}{ }_{2}+2 \mathrm{H}^{+} \rightarrow$ SOD $-\mathrm{Cu}^{+2}+\mathrm{H}_{2} \mathrm{O}_{2}$

$\mathrm{SOD}-\mathrm{Cu}^{+2}+\mathrm{O}^{\circ-}{ }_{2} \rightarrow \mathrm{SOD}-\mathrm{Cu}^{+}+\mathrm{O}_{2}$

$\mathrm{Z}$ kolei powstały $\mathrm{H}_{2} \mathrm{O}_{2}$ jest następnie inaktywowany przez katalazę oraz/lub peroksydazę glutationową, z wytworzeniem $\mathrm{H}_{2} \mathrm{O}[4,22]$. Aktywność SOD stwierdzono m.in. w gonadzie 
i najądrzu bizona [17], szczura [1,31,34] oraz w nasieniu ogiera, knura, szczura [34]. Źródłami SOD w płynie nasiennym psa są najądrze i prostata [17], a u knura najądrze, prostata i gruczoły pęcherzykowe [43]. U bizona wykazano wyższą aktywność dysmutaz w ogonie najądrza, w porównaniu z gonadą czy z głową i trzonem najądrza. W tych dwóch ostatnich wartości były zbliżone [44]. Podobną zależność stwierdzono u knura, gdzie aktywność cytoplazmatycznej cynkowo-miedziowej (Cu-ZnSOD) wzrastała od głowy w kierunku ogona najądrza [45]. Dysmutazy ponadtlenkowe występują zależnie od typu, $\mathrm{w}$ formie dimeru: cytoplazmatyczna Cu-ZnSOD i mitochondrialna manganowa (MnSOD), oraz o budowie tetrameru - zewnątrzkomórkowa cynkowo-miedziowa (EC-SOD). Obecność MnSOD stwierdzono przede wszystkim w macierzy mitochondrialnej, a jej niewielkie ilości w jądrze komórkowym, peroksysomach, lizosomach i przestrzeniach zewnątrzkomórkowych [46]. Najbardziej charakterystyczną dla przestrzeni pozakomórkowych jest jednak EC-SOD. Cynk stabilizuje podjednostki SOD, a miedź uczestniczy w unieszkodliwianiu $0^{\circ-}$. Dysmutaza zewnątrzkomórkowa pełni funkcje ochronne w nasieniu, limfie, płynie śródmiąższowym i mózgowo-rdzeniowym oraz we krwi [4, 20, 47]. Silną ekspresję Cu-ZnSOD wykazano wzdłuż całego najądrza szczura [20], knura [48] oraz w nasieniu psa, gdzie uważa się ją za główny antyoksydant [49]. Zlokalizowano też Cu-ZnSOD w komórkach podstawnych najądrza człowieka, sugerując jej udział w lokalnej ochronie nabłonka [20]. U bizona wielkość ekspresji mRNA Cu-ZnSOD była porównywalna w całym najądrzu oraz jądrze [44]. Z kolei EC-SOD występuje w kanalikach nasiennych, gdzie pełni rolę ochronną w procesie spermatogenezy, w najądrzu oraz w nasieniu knura [45, 48]. Niewielką ilość mRNA EC-SOD wykazano w gonadzie oraz najądrzu bizona, przy czym w jądrze ekspresja była 3-krotnie większa w porównaniu z ogonem i 6-krotnie większa w porównaniu z głową najądrza [44]. Plazma nasienia zawiera więcej aktywnej SOD niż inne płyny pozakomórkowe, głównym źródłem tego enzymu jest prostata. Przy czym Cu-ZnSOD stanowi aż 75\% całkowitej aktywności wszystkich dysmutaz w plazmie nasienia, a EC-SOD (25\%) ogranicza się głównie do wstawki plemników, szczególnie tych o najlepszej ruchliwości [20]. Obecność SOD wykazano również w plemnikach człowieka oraz knura, gdzie chroni ona lipidy przed peroksydacją wywołaną przez $0^{\circ-}[20,43]$. W gametach męskich oznaczano duże ilości MnSOD w mitochondriach wstawki oraz wysoką aktywność Cu-ZnSOD, większą niż w płucach i nerkach. Wykazano, że aktywność SOD w plemnikach jest pozytywnie skorelowana z ich ruchliwością. Wzbogacenie nasienia w EC-SOD minimalizowało spadek ruchliwości gamet w czasie, ponieważ enzym ten chronił błony komórkowe przed degradacją. Każda z form SOD syntetyzowana w komórkach nabłonkowych najądrza jest kodowana przez specyficzny dla niej gen [20].

\section{KATALAZA}

Katalaza jest bardzo aktywną oksydoreduktazą występującą w formie tetrameru, której grupę prostetyczną tworzy hemina (pochodna hemu z jonem żelaza na ${ }^{+} 3$ stopniu utlenienia). Każda podjednostka katalazy wiąże jedną cząsteczkę NADPH, która prawdopodobnie stabilizuje enzym. W wielu komórkach katalaza obecna jest w formie typowej - cytoplazmatycznej i atypowej - peroksysomalnej i, jak wspomniano wcześniej, kontynuuje działanie dysmutaz ponadtlenkowych. Poprzez katalizowanie reakcji dysproporcjonowania $\mathrm{H}_{2} \mathrm{O}_{2}$ prowadzi do wytworzenia cząsteczki $\mathrm{H}_{2} \mathrm{O}$ oraz $\mathrm{O}_{2}$ cząsteczkowego [4]. Choć cała reakcja jest błyskawiczna, w ciągu $60 \mathrm{~s}$ CAT unieszkodliwia nawet do 6 mln cząsteczek $\mathrm{H}_{2} \mathrm{O}_{2}$, to katalaza wykazuje swe właściwości dopiero przy bardzo wysokim poziomie $\mathrm{H}_{2} \mathrm{O}_{2}$ [37]. Na poziomie komórkowym aktywna jest w peroksysomach, mitochondriach, siateczce śródplazmatycznej oraz cytozolu, a tkankowym jej obecność wykazano w gonadzie, najądrzu, nasieniu szczura [43, 50], gonadzie i najądrzu bizona [44]. Przy czym u bizona aktywność CAT była najniższa w ogonie najądrza w porównaniu do innych tkanek męskiego układu płciowego. W gonadzie oraz w trzonie i głowie najądrza aktywność CAT była zbliżona [44]. Niemal 2-3-krotnie wyższą ekspresję mRNA katalazy wykazano w głowie i ogonie najądrza bizona, w porównaniu z trzonem najądrza oraz gonadą [44]. Katalaza obecna w płynie nasiennym człowieka, bizona i myszy może zapobiegać negatywnym skutkom działania nadmiernych stężeń RFT na funkcje plemników [15, 44, 51]. Z kolei badania ejakulatu psów nie wykazały białka enzymatycznego o aktywności katalazy, co pozostaje w zgodzie z wcześniejszymi badaniami tego gatunku $[17,49]$.

\section{PEROKSYDAZY GLUTATIONOWE}

Uważa się, że ważną rolę w utrzymaniu odpowiedniego stężenia RFT mają peroksydazy glutationowe [4, 37]. Wykorzystują one dwie cząsteczki GSH do redukcji $\mathrm{H}_{2} \mathrm{O}_{2}$, podczas jego rozkładu: $2 \mathrm{GSH}+\mathrm{H}_{2} \mathrm{O}_{2} \rightarrow \mathrm{GSSG}+2 \mathrm{H}_{2} \mathrm{O}$. Zapewniają również ochronę przed peroksydacją lipidów $[4,52]: \mathrm{ROOH}+2 \mathrm{GSH} \rightarrow$ $\mathrm{ROH}+\mathrm{GSSG}+\mathrm{H}_{2} \mathrm{O}$. Białka peroksydaz glutationowych (GPX) należą do różnych klas: cytozolowych, wydzielniczych, rozpuszczalnych i związanych z błoną. Jako wydzielnicze znaleziono je w segmencie inicjalnym najądrza myszy, a jako związane z plemnikami w świetle przewodu. Peroksydazy glutationowe są kolejną grupą enzymów wykazanych w gonadzie myszy [53], najądrzu i gonadzie bizona [44], szczura [34, 50] oraz w plemnikach, płynie nasiennym, prostacie, pęcherzykach nasiennych człowieka i myszy [54] oraz w ejakulacie psa [17]. Brak ekspresji GPX w plemnikach korelował z niepłodnością u mężczyzn oraz samców myszy $[55,56,57,58]$. W ejakulowanych plemnikach psa głównym antyoksydantem rozkładającym nadtlenek wodoru jest GPX, a nie CAT [17]. W gonadzie i najądrzu bizona wykazano niższą aktywność GPX niż SOD oraz CAT, przy czym w gonadzie aktywność GPX była wyższa niż w głowie, trzonie i ogonie, a w samym najądrzu najwyższą aktywność wykazano w trzonie [44]. Scharakteryzowano dotychczas kilka rodzajów GPX, kodowanych przez odrębne geny [4]:

- GPX1, cytozolowa i GPX3 osoczowa - występują w formie tetrameru, redukują głównie $\mathrm{H}_{2} \mathrm{O}_{2}$ oraz nadtlenki lipidów [7], 
- GPX2, inna postać cytozolowej formy enzymu, pierwotnie wykazana w układzie pokarmowym gryzoni [7],

- GPX4, PHGPX, peroksydaza glutationowa nadtlenków lipidów, monomer, enzym związany z błonami, pełni istotną funkcję w spermatogenezie $[7,59,60]$,

- GPX5 (epGPX), nie zawiera w centrum katalitycznym selenocysteiny, co jednak nie wpływa negatywnie na jej aktywność antyoksydacyjną [58, 59, 61].

Peroksydazy glutationowe GPX1-GPX4 zawierają selenocysteinę w centrum katalitycznym [4, 59]. W męskim układzie płciowym, zwłaszcza w najądrzu, można wykazać obecność różnych peroksydaz glutationowych (GPX1-GPX5) [44, 59]. W głowie najądrza myszy wykazano sekrecję GPX3 do światła przewodu, a jej obecność stwierdzono również w cytoplazmie komórek nabłonkowych trzonu i ogona najądrza oraz nasieniowodu [7]. Jest to szczególnie ważne z uwagi na małą zdolność regeneracyjną komórek nabłonkowych najądrza. Zaobserwowano różny wpływ kastracji na poziom mRNA GPX3 i GPX5 w najądrzu. Uważa się, że kontrola androgenna może być pośrednia, przy udziale tkankowo specyficznego czynnika transkrypcyjnego. Może nim być np. białko PEA3 (polyomavirus enhancer activator 3), ulegające ekspresji w głowie najądrza [62]. Badania wykazały, że ekspresja gpx3 u myszy pozostaje pod kontrolą androgenów jedynie w trzonie i ogonie najądrza, w przeciwieństwie do głowy [7].

Peroksydaza glutationowa nadtlenków lipidów wykazuje większe powinowactwo do nadtlenków lipidów i cholesterolu niż do $\mathrm{H}_{2} \mathrm{O}_{2}[7,52,60]$. Ekspresję GPX4 u mężczyzn wykazano głównie w gonadzie, w różnicujących się komórkach germinalnych, brak jej natomiast w komórkach Sertoliego [58]. Uważa się, że GPX4 jest główną peroksydazą jąder różnych gatunków ssaków (np. bizona) [44]. Ekspresja mRNA dla GPX4 w gonadzie bizona była wyższa niż dla GPX5 i CAT, była też wyższa niż w najądrzu tych zwierząt [44]. W plemnikach najądrzowych knura oznaczono białko GPX4, którego poziom wzrastał w trakcie dojrzewania gamet [45]. Wykazano również enzymatycznie nieaktywne, nierozpuszczalne, strukturalne białko GPX4 w osłonce mitochondrialnej plemników [7]. Specyficzną odmianą GPX4 jest snGPX4 związana z protaminami. Pełni ona zasadnicza rolę w kondensacji materiału genetycznego w główce plemników, poprzez oksydację protamin, w czasie wędrówki gamet przez najądrze [37], chroni zatem materiał genetyczny przed mutagennym działaniem RFT [7]. U myszy pozbawionych aktywnych genów sngpx4 i gpx5 wykazano, że 30-35\% populacji plemników w głowie najądrza posiadało dużą główkę, co było związane z niewielką kondensacją materiału genetycznego. Pomimo to, u mutantów wykazano zbliżony poziom MDA w homogenatach najądrzy, niższy w plemnikach oraz porównywalną liczbę gamet w ogonie najądrza [37].

Peroksydazy glutationowe GPX1 i cGPX4 są enzymami obecnymi wewnątrz komórek nabłonkowych najądrzy ssaków, podczas gdy GPX5 jest białkiem wydzielniczym [4]. Większość (95\%) wszystkich peroksydaz, zarówno na poziomie mRNA, jak i białka, to GPX3 i GPX5. Wykazano, że GPX3 obecna jest we wzrastających stężeniach od głowy do ogona najądrza, podczas gdy zarówno ekspresja, jak i sekrecja GPX5 ograniczona jest do głowy najądrza, natomiast zakumulowana jest w ogonie najądrza magazynującym plemniki przez wiele dni, co koreluje z koniecznością ochrony przed uszkodzeniem peroksydacyjnym [44]. Natomiast GPX1 i cGPX4 syntetyzowane są w niewielkich ilościach wzdłuż całego najądrza. Zatem uważa się, że główną funkcję ochronną wobec komórek nabłonkowych najądrzy pełni GPX3, a wobec przedziału luminalnego GPX5 [44, 59].

Jak wykazały badania, ekspresja GPX 5 pozostaje pod kontrolą androgenów [36]. Ekspresję genu gpx5 wykazano m.in. w segmencie inicjalnym najądrza szczura [20], w głowie i ogonie najądrza myszy [58] i bizona, przy czym u bizona najsilniejszą ekspresję stwierdzono w głowie najądrza (30-krotnie wyższą) w porównaniu z ogonem, a niższą w trzonie najądrza i w gonadzie [44]. Wydzielana w głowie najądrza GPX5 wiąże się z główką plemników przemieszczających się wzdłuż przewodu i chroni je przed RFT [7]. Herbette i wsp. [61] uważają, że GPX5 związana z błoną plemnika w okolicy akrosomu chroni przed przedwczesną reakcją akrosomalną, inaktywując nadtlenki lipidów, które mogłyby indukować tę reakcję. W odróżnieniu od niektórych innych białek GPX5 nie jest reabsorbowana podczas tranzytu przez najądrze, a uwalniana jest z błony główki plemnika dopiero w żeńskich drogach rodnych i odgrywa rolę podczas zapłodnienia [7].

Peroksydazy glutationowe ulegające ekspresji w najądrzu GPX1, GPX3, GPX4 i GPX5 mają wyjątkową rolę w zapewnieniu optymalnego dla plemników stężenia RFT [7, 59]. Enzymy te uczestniczą w tej samej reakcji, co CAT, z tym, że dodatkowo mogą przywracać zredukowaną formę wielonienasyconych kwasów tłuszczowych, dzięki czemu naprawiają związki uszkodzone przez peroksydację [59]. Przeprowadzone w ciągu ostatnich lat doświadczenia na myszach pozbawionych aktywnego genu gpx, wykazały ich niepłodność i potwierdziły, że enzymy są istotne w fizjologii plemników ssaków $[58,59]$.

\section{GLUTATION}

Nieenzymatycznym antyoksydantem w męskim układzie płciowym jest glutation (gamma-glutamylocysteinyloglicyna) [4]. Występuje on w komórce w kilku postaciach: mieszanych disiarczków glutationu i białek, S-nitrozoglutationu, utlenionej - GSSG i zredukowanej. Większość glutationu w komórce (98\%) stanowi GSH, który umożliwia utrzymanie w niezmienionej formie grup sulfhydrylowych białek, detoksykuje ksenobiotyki oraz „zmiata” wolne rodniki [22, 63]. Grupa tiolowa GSH może ulec utlenieniu, co prowadzi do powstania GSSG, który stanowi ok. 1\% puli glutationu komórkowego [63].

Utlenienie glutationu znacznie przyspiesza GPX, gdy czynnikiem utleniającym jest nadtlenek wodoru lub nadtlenki organiczne. Reakcje GSH z wolnymi rodnikami substancji organicznych (np. białek) mogą prowadzić do ich naprawy kosztem utworzenia wolnego rodnika glutationu, rodnika tiylowego (GS ). Powstałe rodniki GS ${ }^{*}$ rekombinują ze sobą i powstaje GSSG. Może on być niebezpieczny dla komórki, gdyż może prowadzić do inaktywacji białek, tworząc mieszane disulfidy 
z białkami zawierającymi grupy tiolowe lub utleniając grupy tiolowe białek, co prowadzi do powstania mostków disulfidowych.

Utleniony glutation jest aktywnie transportowany z cytoplazmy na zewnątrz komórki. Jednak błony mitochondrialne nie są zdolne do takiego transportu, dlatego utlenienie glutationu mitochondrialnego, który stanowi ok. 10\% glutationu komórki, uważa się za bardziej niebezpieczne [22, 63]. Właściwości antyoksydacyjne glutationu zapewnia obecność grup tiolowych. Glutation zredukowany bierze udział we wszystkich trzech liniach obrony antyoksydacyjnej [4]. Reaguje z bardzo dużą szybkością z ${ }^{\bullet} \mathrm{OH}$ oraz mniejszą z $\mathrm{O}^{\bullet-}{ }_{2}[4,22]$. Jest kofaktorem takich enzymów antyoksydacyjnych, jak GPX i S-transferazy glutationowe (GST), uczestniczy bezpośrednio w usuwaniu $\cdot \mathrm{OH}, \mathrm{O}^{--}{ }_{2}, \mathrm{H}_{2} \mathrm{O}_{2},{ }^{1} \mathrm{O}_{2}$, a także utrzymuje w równowadze grupy tiolowe białek $[3,63]$.

Poza „zmiataniem” RFT i regeneracją innych drobnocząsteczkowych antyoksydantów GSH uczestniczy także w odtwarzaniu uszkodzonych składników komórki, głównie białek i lipidów błon komórkowych oraz DNA [63, 64]. Glutation jest nie tylko ważnym antyoksydantem, ale również źródłem aminokwasów dla różnicujących się gamet w procesie spermatogenezy [19]. Obecność GSH, którego źródłem są m.in. komórki Sertoliego, stwierdza się w homogenatach jąder i najądrzy szczura [45, 50], w nasieniu mężczyzn [3], a także w plemnikach [19]. Frączek i Kurpisz [19] donoszą, że stężenie GSH wzrasta w płynie najądrza, w kierunku ogona. Jak wykazały badania, stężenie GSH w nasieniu mężczyzn jest pozytywnie skorelowane z ruchliwością plemników [3]. Niedobór GSH może powodować niestabilność wstawki plemników i zaburzać morfologię oraz ruchliwość gamet [65]. Według Gutman [65] suplementacja GSH może ochronić przed nowotworzeniem w obrębie prostaty, poprawiać jakość nasienia i zwiększyć płodność.

\section{S-TRANSFERAZY GLUTATIONOWE}

Ochronna rola GSH zależy od enzymów związanych z nim funkcjonalnie (np. GST). Enzymy te wykazują szeroką specyficzność substratową. Mogą przyłączać GSH do wielu różnych, czasem toksycznych dla organizmu związków, m.in. aldehydowych produktów peroksydacji lipidów. Dzięki temu ksenobiotyki oraz RFT i ich metabolity stają się mniej toksyczne, rozpuszczalne w wodzie i mogą być łatwiej usuwane z komórek organizmu $[63,66]$. Transferazy glutationu to białka o budowie dimeru, które mogą różnić się aktywnością wobec różnych substancji ze względu na możliwą różnorodność swej budowy. Aktywność GST wykazano m.in. w gonadzie myszy, szczura [53, 67] oraz najądrzu i nasieniu szczura [50, 67]. Stwierdzono, że aktywność GST u szczura wzrasta wraz z wiekiem, co prawdopodobnie jest związane ze wzrostem poziomu epoksydów oraz organicznych nadtlenków, które są naturalnymi substratami dla GST [64]. Beverdam i wsp. [68] stwierdzili silną ekspresję genu gstm6 w komórkach Sertoliego, niższą w okołokanalikowych komórkach mioidalnych jąder mysich u embrionów, a także u osobników dojrzałych płciowo, co zwiększa ochronę komórek germinalnych [66]. Wyniki badań molekularnych wykazały, że ekspresja gstm6 zależy od ekspresji genu sox9, który determinuje rozwój płci w kierunku męskim i odpowiada za prawidłowy rozwój jąder. Można przypuszczać, że gstm6 pełni specyficzną rolę w rozwoju gonad i ich funkcjonowaniu w życiu dorosłym [66]. Inni badacze wykazali wysoką ekspresję mRNA dla podjednostek GST w najądrzu myszy, przy czym u zwierząt pozbawionych genów kodujących snGPX4 i GPX5 wykazano zwiększoną ekspresję gst- $\mu$ i gst- $\pi$ [37]. Wykazano najwyższą ekspresję charakterystycznej dla najądrza podjednostki 7 pi (GST7-7) w segmencie inicjalnym oraz w ogonie najądrza [64].

\section{REDUKTAZA GLUTATIONU}

Powstający wskutek reakcji z RFT utleniony glutation musi być ponownie zredukowany do GSH. Odpowiada za to reduktaza glutationu (GR), której kofaktorem jest NADPH [20, 64]. Jest ona enzymem o masie $22 \mathrm{kDa}$ katalizującym reakcje wzajemnych przemian grup sulfhydrylowych i disiarczków [4]. Ekspresję białka oraz aktywność GR wykazano w jądrze oraz najądrzu szczura [50, 65, 69, 70]. Wśród tkanek męskiego układu płciowego szczura najwyższy poziom mRNA dla GR i białka enzymatycznego oraz najwyższą aktywność tego enzymu wykazano w najądrzu, w porównaniu do jądra, prostaty, pęcherzyków nasiennych czy nasieniowodu [62].

\section{TRANSPEPTYDAZA GAMMA-GLUTAMYLOWA}

Enzymem, który przywraca w sposób pośredni zredukowaną postać glutationu, jest transpeptydaza $\gamma$-glutamylowa (GGT) [4, 64]. Utrzymuje zatem homeostazę glutationu i cysteiny, bierze także udział w metabolizmie ksenobiotyków oraz leukotreinu $\mathrm{C}_{4}$, przez co jest istotny zarówno w obronie antyoksydacyjnej, detoksykacji, jak i w procesach zapalnych [4, 63]. Istnieje wiele odmian GGT różniących się wskutek modyfikacji potranslacyjnych [43, 62, 71]. Wykazano, że w najądrzu człowieka ekspresja GGT zależy od czynników pochodzących z gonady [36]. Obecność GGT jako integralnej, błonowej glikoproteiny, o budowie heterodimeru, stwierdzono na szczytowej powierzchni komórek przewodu najądrza [62]. Aktywność GGT wykazano m.in. w gonadzie oraz nasieniu szczura [67]. Wśród substancji pełniących funkcje obronne przed działaniem RFT w męskim układzie płciowym ważną rolę odgrywają również drobnocząsteczkowe antyoksydanty. Dzielą się one na hydrofilowe (funkcje obronne w środowisku wodnym komórki) i hydrofobowe (działające w środowisku lipidowym) [34].

\section{WITAMINA C}

Do najważniejszych antyoksydantów hydrofilowych, poza glutationem, należy kwas askorbinowy (witamina C, askorbinian). Pełni on funkcje obronne wewnątrz komórek, ale przede wszystkim w płynach pozakomórkowych, gdzie występuje 
w postaci anionu askorbinianowego [24, 25, 28]. Stężenie askorbinianu w płynie nasiennym jest 10-krotnie wyższe niż w osoczu i jest pozytywnie skorelowane z procentowym udziałem prawidłowych plemników, w których stwierdzono jedynie niskie stężenie askorbinianu [65]. Witamina C dezaktywuje zarówno wolne rodniki tlenowe $\left(\mathrm{O}^{\circ-}{ }_{2},{ }^{\circ} \mathrm{OH}, \mathrm{RO} 0^{*}, \mathrm{ROO}\right)$, jak i ${ }^{1} \mathrm{O}_{2}$, chroni także przed nadmierną peroksydacją lipidów, zabezpiecza DNA przed szkodliwym działaniem $\mathrm{H}_{2} \mathrm{O}_{2}$ i przeciwdziała aglutynacji plemników [65]. Badania potwierdziły, że utleniona postać witaminy C (dehydroaskorbinian) poprzez stymulację aktywności enzymów cyklu pentozowego (dehydrogenazy glukozo-6-fosforanowej, dehydrogenazy 6-fosfoglukonianowej i transaldolazy) podnosi poziom GSH [72]. Badania niepłodnych mężczyzn wykazały, iż stężenie askorbinianu w plazmie nasienia było u nich obniżone, a fragmentację DNA w plemnikach stwierdzano częściej u pacjentów z niskim poziomem askorbinianu w plazmie nasienia [3].

\section{ANTYOKSYDANTY FAZY HYDROFOBOWEJ}

Głównym antyoksydantem w fazie hydrofobowej komórki jest witamina E. Tworzą ją cztery tokoferole $(\alpha, \beta, \gamma, \delta)$ o 16-węglowym łańcuchu fitylowym oraz cztery tokotrienole $(\alpha, \beta, \gamma, \delta)$ posiadające w wymienionym łańcuchu fitylowym trzy wiązania podwójne. Witamina E zawiera najwięcej tokoferolu $\alpha$ (88\%), który występuje w błonach komórkowych oraz w lipoproteinach osocza krwi [24, 25]. Najważniejszą funkcją witaminy E jako antyoksydanta jest dezaktywacja wolnych rodników organicznych, dzięki czemu przerywa ona reakcję łańcuchową utleniania lipidów: lipid-00 + witamina E $\rightarrow$ lipid-OOH + witamina $\mathrm{E}^{*}$, gdzie: lipid-00 to wolny rodnik nadtlenku lipidu, witamina $\mathrm{E}^{\bullet}$ to rodnik tokoferylowy [21]. Powstały rodnik tokoferylowy jest znacznie mniej reaktywny w porównaniu z rodnikiem nadtlenku lipidu i może uczestniczyć w reakcji z innym rodnikiem nadtlenkowym lub ulegać redukcji w obecności innych związków [4, 22]. Witamina E chroni plemniki przed uszkodzeniami oksydacyjnymi i spadkiem ruchliwości, przyczynia się także do prawidłowej penetracji osłonki przejrzystej komórki jajowej. Dodatkowo suplementacja witaminą E obniża poziom MDA w plemnikach do wartości prawidłowych [65].

Witamina E jest głównym antyoksydantem związanym z błoną komórkową plemników. Wzbogacenie diety w witaminę E zwiększa koncentrację i właściwości biologiczne plemników w ejakulacie knura [43]. Golbidi i Laher [3] stwierdzili istotne obniżenie peroksydacji lipidów oraz wzrost ruchliwości plemników u mężczyzn z astenozoospermią, którzy przyjmowali witaminę E (100 mg 3 razy dziennie przez 6 miesięcy) [3]. Witamina E poprzez synergistycznie działanie z witaminą C, in vivo, może zmniejszać peroksydacyjne uszkodzenia plemników [30].

Należy jeszcze wymienić pochodne retinolu (witamina A). Występuje on w dwóch podstawowych formach: retinolu i 3,4-didehydroretinolu. Badania potwierdzają antyoksydacyjne działanie witaminy A, które polega na reagowaniu z rodnikiem nadtlenkowym oraz na hamowaniu łańcucha reakcji wolnorodnikowych [73, 74].

\section{METALOTIONEINY}

Własności antyoksydacyjne posiadają również niskocząsteczkowe białka - metalotioneiny (MT), które zawierają w swojej cząsteczce dużo reszt cysteinylowych oraz atomy metali ciężkich (np. kadm, rtęć) lub cynk czy miedź. Zbudowane są z łańcucha polipeptydowego o długości 61-68 aminokwasów. Cząsteczka MT zbudowana jest z dwóch domen $\alpha$ i $\beta$ połączonych dimerem lizynowym [74, 75]. Związki te wiążą atomy metali, a ponadto reagują z dużą szybkością z rodnikami ${ }^{\bullet} \mathrm{OH} \mathrm{i} \mathrm{O}^{\circ-}{ }_{2}$. Obecność MT stwierdzono w całym męskim układzie płciowym, w tym w prostacie i pęcherzykach nasiennych. Wykazano wysoki poziom MT I i MT II w spermatocytach pachytenowych i spermatydach, natomiast niski poziom w komórkach Sertoliego i Leydiga. Ekspresją mRNA dla MT III wykryto w najądrzach i prostatcie, chociaż nie ma informacji na temat regulacji MT w różnych regionach najądrza [76]. Syntezę MT indukują m.in. metale ciężkie, jony cynku, hormony i RFT [77]. Podczas stresu oksydacyjnego cynk uwalniany jest z MT, wtedy ich grupy tiolowe stają się głównymi substratami dla RFT (np. $\mathrm{H}_{2} \mathrm{O}_{2}$ ), dzięki czemu oszczędzany jest GSH. Uwolniony cynk wiąże się z białkami błonowymi i w ten sposób zabezpiecza błony przed zmianami strukturalnymi. Metalotioneiny wykazują 10-krotnie wyższą wydajność w porównaniu do glutationu, w neutralizacji nadtlenków lipidów oraz w hamowaniu peroksydacji lipidów błonowych [78].

\section{TRANSFERYNA}

Kolejnym białkiem o właściwościach antyoksydacyjnych jest transferyna (Tf). W układzie rozrodczym ssaków odgrywa ona ważną rolę w procesach steroidogenezy oraz spermatogenezy [62]. U szczurów Tf dostarcza jony żelaza spermatocytom i spermatydom z przedziału adluminalnego i prawdopodobnie jest uwalniana jako apotransferyna do przestrzeni międzykomórkowej oraz płynu kanalikowego [62]. Badania wykazały, że Tf bierze udział w produkcji prawidłowych plemników u myszy. Wykazano, że Tf należy do najważniejszych antyoksydantów w plazmie nasienia człowieka, a jej głównym źródłem są komórki Sertoliego. Poziom Tf jest markerem aktywności tych komórek. Poprzez podaż żelaza Tf jest zaangażowana w rozwój i różnicowanie komórek rozrodczych oraz chroni błony komórkowe plemników przed uszkodzeniami peroksydacyjnymi. Ponadto wykazano dodatnią korelację pomiędzy stężeniem Tf $\mathrm{w}$ plazmie nasienia człowieka a liczbą plemników [78].

\section{PODSUMOWANIE}

Reaktywne formy tlenu mogą pełnić w męskim układzie płciowym zarówno ważne funkcje fizjologiczne m.in. w sygnalizacji komórkowej, w procesach spermatogenezy oraz najądrzowego dojrzewania plemników, jak i wywoływać stres oksydacyjny, którego skutkiem może być uszkodzenie błon 
plemników, zawartego w nich DNA, zahamowanie ruchliwości oraz zmniejszenie zdolności do zapłodnienia. Stres oksydacyjny uznawany jest obecnie za jedną z możliwych przyczyn coraz częściej stwierdzanej męskiej niepłodności [20]. Ten podwójny efekt działania RFT potwierdza szczególną rolę antyoksydantów enzymatycznych (m.in. SOD, CAT, GPX, GR, GST, GGT) i nieenzymatycznych (m.in. GSH, witaminy A, E, C, transferyna), które są odpowiedzialne za utrzymywanie odpowiedniego stężenia RFT w męskim układzie płciowym.

\section{PIŚMIENNICTWO}

1. Barrat C, Mansell S, Beaton C, Tardif S, Oxenham SK. Diagnostic tools in male infertility - the question of sperm dysfunction. Asian J Androl 2011;13(1):53-8

2. Bablok L, Dziadecki W, Szymusik I, Wolczyński S, Kurzawa R, Pawelczyk L, et al. Patterns of infertility in Poland - multicenter study. Neuro Endo Lett 2011;32(6):799-804.

3. Golbidi S, Laher I. Antioxidant therapy in human endocrine disorders. Med Sci Monit 2010;16(1):9-24

4. Asani BA, Ghobadi S. Studies on antioxidants with a brie glance at their relevance to the immune system. Life Sci 2016;146:163-73.

5. Ko EY, Sabanehg ES Jr, Agarwal A. Male infertility testing: reactive oxygen species and antioxidant capacity. Fertil Steril 2014;102(6):1518-27.

6. Aitken RJ, Baker MA, De Iuliis GN, Nixon B. New insights into sperm physiology and pathology. Handb Exp Pharmacol 2010;198:99-115.

7. Chabory E, Damon C, Lenoir A, Henry-Berger J, Vernet P, Cadet R, et al. Mammalian glutathione peroxidases control acquisition and maintenance of spermatozoa integrity. J Anim Sci 2010;88(4):1321-31.

8. de Lamirande E, Lamothe G. Levels of semenogelin in human spermatozoa decrease during capacitation: involvement of reactive oxygen species and zinc. Hum Reprod 2010;25(7):1619-30.

9. Donà G, Fiore C, Andrisani A, Ambrosini G, Brunati A, Ragazzi E, et al. Evaluation of correct endogenous reactive oxygen species content for human sperm capacitation and involvement of the NADPH oxidase system. Hum Reprod 2011;26(12):3264-73.

10. Donà G, Fiore C, Tibaldi E, Frezzato F, Andrisani A, Ambrosini G, et al. Endogenous reactive oxygen species content and modulation of tyrosine phosphorylation during sperm capacitation. Int J Androl 2011;34(5 Pt 1):411-9.

11. Lombardo F, Sansone A, Romanelli F, Paoli D, Gandini L, Lenzi A. The role of antioxidant therapy in the treatment of male infertility: an overview. Asian J Androl 2011;13(5):690-7.

12. Bansal AK, Bilaspuri GS. Impacts of oxidative stress and antioxidants on semen functions. Vet Med Int 2010. doi: 10.4061/2011/686137.

13. Kazama M, Hino A. Sea urchin spermatozoa generate at least two reactive oxygen species; the type of reactive oxygen species changes under different conditions. Mol Reprod Dev 2012;79(4):283-95.

14. Saalu LC. The incriminating role of reactive oxygen species in idiopathic male infertility: an evidence based evaluation. Pak J Biol Sci 2010;13(9):413-22.

15. Sánchez R, Sepúlveda C, Risopatrón J, Villegas J, Giojalas LC. Human sperm chemotaxis depends on critical levels of reactive oxygen species. Fertil Steril 2010;93(1):150-3.

16. Henkel RR. Leukocytes and oxidative stress: dilemma for sperm function and male fertility. Asian J Androl 2011;13(1):43-52.

17. Koziorowska-Gilun M, Strzeżek R. Molecular forms of selected antioxidant enzymes in dog semen - electrophoretical identification. Pol J Vet Sci 2011;14(1):29-33.

18. Coskun P, Wyrembak J, Debereva O, Melkonian G, Doran E, Lott I, et al. Systemic mitochondria dysfunction and the etiology of Alzheimer's disease and down syndrome dementia. J Alzheimers Dis 2010;20(Suppl 2):293-310.

19. Frączek M, Kurpisz M. System redox w nasieniu męskim i peroksydacyjne uszkodzenia plemników. Postępy Hig Med Dośw 2005;59:523-34.

20. Pandey R, Singh M, Singhal U, Gupta KB, Aggarwal SK. Oxidative/Nitrosative stress and the pathobiology of chronic obstructive pulmonary disease. J Clin Diagn Res 2013;7(3):580-8.
21. Karpińska A, Gromadzka G. Stres oksydacyjny i naturalne mechanizmy antyoksydacyjne - znaczenie w procesie neurodegeneracji. Od mechanizmów molekularnych do strategii terapeutycznych. Postępy Hig Med Dośw 2013;67:43-53.

22. Bartosz G. Druga twarz tlenu. Warszawa: PWN; 2003.

23. Khaki A, Fathiazad F, Nouri M, Khaki AA, Maleki NA, Khamnei HJ, et al. Beneficial effects of quercitin on sperm parameters in streptozotocin-induced diabetic male rats. Phytother Res 2010;24(9):1285-91.

24. Ruiz-Ramos M, Vargas LA, van Der Goes TIF, Cervantes-Sandoval A, Mendoza-Núñez VM. Supplementation of ascorbic acid and alpha-tocopherol is useful to preventing bone loss linked to oxidative stress in elderly. J Nutr Heath Aging 2010;14(6):467-72.

25. Takhshid MA, Tavasuli AR, Heidary Y, Keshavarz M, Kargar H. Protective effect of vitamins $\mathrm{E}$ and $\mathrm{C}$ on endosulfan-induced reproductive toxicity in male rats. Iran J Med Sci 2012;37(3):173-80.

26. Aitken RJ, Jones KT, Robertson SA. Reactive oxygen species and sperm function - in sickness and in health. J Androl 2012;33(6):1096-106.

27. Kazama M, Fiore C, Andrisani A, Ambrosini G, Brunati A, Ragazzi E, et al. Evaluation of correct endogenous reactive oxygen species content for human sperm capacitation and involvement of the NADPH oxidase system. Hum Reprod 2011;26(12):3264-73.

28. Karunakaran U, Park KG. A systematic review of oxidative stress and safety of antioxidants in diabetes: focus on islets and their defense. Diabetes Metab J 2013;37(2):106-12.

29. Mammucari C, Rizzuto R. Signaling pathways in mitochondrial dysfunction and aging. Mech Ageing Dev 2010;131(7-8);536-43.

30. Lanzafame FM, La Vignera S, Vicari E, Calogero AE. Oxidative stress and medical antioxidant treatment in male infertility. Reprod Biomed Online 2009;19(5):638-59.

31. Przybyszewski WM, Rzeszowska-Wolny J. Oxidative stress in prostate hypertrophy and carcinogenesis. Postępy Hig Med Dośw 2009;63:340-50.

32. Melchers A, Stockl L, Radszewski J, Anders M, Krenzlin H, Kalischke C, et al. A systematic proteomic study of irradiated DNA repair deficient Nbn-mice. PLOs One 2009;4(5):e5423.

33. Marchlewicz M, Baranowska-Bosiacka I, Kolasa A, Kondarewicz A, Chlubek D, Wiszniewska B. Disturbances of energetic metabolism in rat epididymal epithelial cells as a consequence of chronic lead intoxication. Biometals 2009;22(6):877-87.

34. Marchlewicz M, Wiszniewska B, Gonet B, Baranowska-Bosiacka I, Safranow K, Kolasa A, et al. Increased lipid peroxidation and ascorbic acid utilization in testis and epididymis of rats chronically exposed to lead. Biometals 2007;20(1):13-9.

35. Marchlewicz M, Michalska T, Wiszniewska B. Detection of lead-induced oxidative stress in the rat epididymis by chemiluminescence. Chemosphere 2004;57(10):1553-62.

36. Belleannèe $\mathrm{C}$, Thimon $\mathrm{V}$, Sullivan R. Region-specific gene expression in the epididymis. Cell Tissue Res 2012;349(3):7177-31.

37. Noblanc A, Peltier M, Damon-Soubeyrand CH, Kerchkove N, Chabory E, Vernet $\mathrm{P}$, et al. Epididymis response partly compensates for spermatozoa oxidative defects in snGPx4 and GPx5 double mutant mice. PLoS One 2012;7:38565.

38. Zhou D, Wang H, Zhang J. Di-n-butyl phthalate (DBP) exposure induces oxidative stress in epididymis of adult rats. Toxicol Ind Health 2011;27(1):65-71.

39. Djordiević NZ, Babić GM, Marković SD, Ognjanović BI, Stajn AS, Saicić ZS. The antioxidative effect of estradiol therapy on erythrocytes in women with preeclamsia. Reprod Toxicol 2010;29(2):231-6.

40. Saste-Serra J, Valle A, Company MM, Garau I, Oliver J, Roca P. Estrogen down-regulation uncoupling proteins and increases oxidative stress in breast cancer. Free Radic Biol Med 2010;48(4):506-12.

41. Aitken RJ, De Iuliis GN. On the possible origins of DNA damage in human spermatozoa. Mol Hum Reprod 2010;16(1):3-13.

42. Centola GM, Blanchard A, Demick J, Li S, Eisenberg ML. Decline in sperm count and motility in young adult men from 2003 to 2013: observations from a U.S. sperm bank. Andrology 2016;4(2):270-6.

43. Okrasa S, Strzeżek J. Postęp w badaniach dotyczących procesów rozrodczych u świń. Post Nauk Rol 2007;3:65-94

44. Koziorowska-Gilun M, Gilun P, Fraser L, Koziorowski M, Kordan W, Stefanczyk-Krzymowska S. Antioxidant enzyme activity and mRNA expression in reproductive tract of adult male European bison (Bison bonasus, Linnaeus 1758). Reprod Domest Anim 2013;48(1):7-14. 
45. Park K, Jeon S, Song YJ, Yi LSH. Proteomic analysis of boar spermatozoa and quantity changes of superoxide dismutase 1 , glutathione peroxidase, and peroxiredoxin 5 during epididymal maturation. Anim Reprod Sci 2012;135(1-4):53-61.

46. Barbosa AC, Lajolo FM, Genovese MI. Effect of free or protein-associated soy isoflavones on the antioxidant status in rats. J Sci Food Agric 2011;91(4):721-31.

47. Liu Q, Zhou YF, Duan RJ, Wei HK, Jiang SW, Peng J. Effects of dietary n-6:n-3 fatty acid ratio and vitamin $E$ on semen quality, fatty acid composition and antioxidant status in boars. Anim Reprod Sci 2015;162:11-9.

48. Strzeżek R, Koziorowska-Gilun M, Kowalówka M, Strzeżek J. Characteristics of antioxidant system in dog semen. Pol J Vet Sci 2009;12(1):55-60.

49. Kowalowka M, Wysocki P, Fraser L, Strzezek J. Extracellular superoxide dismutase of boar seminal plasma. Reprod Domest Anim 2008;43(4):490-6.

50. Abarikwu SO, Otuechere CA, Ekor M, Monwuba K, Osobu D. Rutin ameliorates cyclophosphamide-induced reproductive toxicity in male rats. Toxicol Int 2012;19(2):207-14.

51. Libman J, Gabriel MS, Sairam MR, Zini A. Catalase can protect spermatozoa of FSH receptor knock-out mice against oxidant-induced DNA damage in vitro. Int J Androl 2010;33(6):818-22.

52. Pajović SB, Saičić ZS. Modulation of antioxidant enzyme activities by sexual steroid hormones. Physiol Res 2008;57(6):801-11.

53. de Freitas ML, Dalmolin L, Oliveira LP, Moreira LR, Roman SS, Soares FA et al. Effects of butane-2,3-dione thiosemicarbazone oxime on testicular damage induced by cadmium in mice. J Toxicol Sci 2012;37(5):899-910.

54. Tremellen K. Oxidative stress and male infertility a clinical perspective. Hum Reprod Update 2008;14(3):243-58.

55. Vilagran I, Castillo J, Bonet S, Sancho S, Yeste M, Estanyol JM, et al: Ac rosin-binding protein (ACRBP) and triosephosphate isomerase (TPI) are good markers to predict boar sperm freezing capacity. Theriogenology 2013;80(5):443-50.

56. Vilagran I, Yeste M, Sancho S, Casas I, Rivera del Álamo MM, Bonet S: Relationship of sperm small heat-shock protein 10 and voltage-dependent anion channel 2 with semen freezability in boars. Theriogenology 2014;82(3):418-26.

57. Vilagran I, Yeste M, Sancho S, Castillo J, Oliva R, Bonet S. Comparative analysis of boar seminal plasma proteome from different freezability ejaculates and identification of Fibronectin 1 as sperm freezability marker. Andrology 2015;3(2):345-56.

58. Shi LG, Xun WJ, Yue WB, Zhang CX, Ren YS, Wang Q, et al. Cloning, characterization, and expression analysis of goat (Capra hircus) phospholipid hydroperoxide glutathione peroxidase (PHGPx). Int J Biol Sci 2010;6(4):316-26.

59. Noblanc A, Kocer A, Chabory E, Vernet P, Saez F, Cadet R, et al. Glutathione peroxidases at work on epididymal spermatozoa: an example of the dual effect of reactive oxygen species o mammalian male fertilizing ability. J Androl 2011;32(6):641-50.

60. Chabory E, Damon C, Lenoir A, Kauselmann G, Kern H, Zevnik B, et al. Epididymis seleno-independent glutathione peroxidase 5 maintains sperm DNA integrity in mice. J Clin Invest 2009;119(7):2074-85.
61. Herbette S, Roeckel-Drevet P, Drevet JR. Seleno-independent glutathione peroxidases. More than simple antioxidant scavengers. FEBS J 2007;274(9):2163-80.

62. Murata M, Kawanishi S. Mechanisms of oxidative DNA damage induced by carcinogenic arylamines. Front Biosci 2011;16:1132-43.

63. Bukowska B. Funkcje glutationu oraz czynniki zmniejszające jego stężenie. Med Pr 2005;56:69-80.

64. Agarwal A, Sekhon LH. The role of antioxidant therapy in the treatment of male infertility. Hum Fertil (Camb) 2010;13(4):217-25.

65. Gutman J. Glutation twój klucz do zdrowia. Warszawa: Skoczek; 2010. p. 185.

66. Kumari M, Singh P. Tribulus terrestris ameliorates metronidazole-induced spermatogenic inhibition and testicular oxidative stress in the laboratory mouse. Indian J Pharmacol 2015;47:304-10.

67. Farombi EO, Adedara IA, Ebokaiwe AP, Teberen R, Ehwerhemuepha T. Nigerian Bonny light crude oil disrupts antioxidant systems in testes and sperm of rats. Arch Environ Contam Toxicol 2010;59(1):166-74.

68. Beverdam A, Svingen T, Bagheri-Fam S, Bernard P, McClive P, Robson M, et al. Sox9-dependent expression of Gstm6 in Sertoli cells during testis development in mice. Reproduction 2009;137(3):481-6.

69. Farias JG, Puebla M, Acevedo A, Tapia PJ, Gutierrez E, Zepeda A, et al. Oxidative stress in rat testis and epididymis under intermittent hypobaric hypoxia: protective role of ascorbate supplementation. J Androl 2010;31(3):314-21.

70. Zhang H, Forman HJ. Redox regulation of $\gamma$-glutamyl transpeptidase. Am J Respir Cell Mol Biol 2009;41(5):509-15.

71. Root-Bernstein R, Fewins J, Rhinesmith T, Koch A, Dillon PF. Enzymatic recycling of ascorbic acid from dehydroascorbic acid by glutathione-like peptides in the extracellular loops of aminergic G-protein coupled receptors. J Mol Recognit 2016, doi: 10.1002/jmr.2530.

72. Grigorescu R, Gruia MI, Nacea V, Nitu C, Negoita V, Glavan D. The evaluation of non-enzymatic antioxidants effects i limiting tumor-associated oxidative stress in a tumor rat model. J Med Life 2015;8(4):513-6.

73. Alpsoy L, Yalvac ME. Key roles of vitamins A, C and E in aflatoxin B1-induced oxidative stress. Vitam Horm 2011;86:287-305.

74. Fic M, Puła B, Rogala K, Dzięgiel P. Rola ekspresji metalotionein w rakach przewodu pokarmowego. Postepy Biol Kom 2013;40:5-20.

75. Sakulsak N. Metallothionein: An overview on its metal homeostatic regulation in mammals. Int J Morphol 2012;30:1007-12.

76. Stępkowaska I. Właściwości biologiczne metalotionein i ich udział w procesach oksydoredukcyjnych w komórkach, ze szczególnym uwzględnieniem ośrodkowego układu nerwowego człowieka. Postepy Biol Kom 2010;4:869-85

77. Cyr DG, Dufresne J, Pillet S, Alfieri TJ, Hermo L. Expression and regulation of metallothioneins in the rat epididymis. J Androl 2001;22(1): 124-35.

78. Spengler K. Pomiar stężenia oksydantów (RFT) i antyoksydantów (TAS, transferyna, ferrytyna, albumina) w nasieniu ludzkim a także wpływ integralności DNA na procesy IVF i ICSI. Praca doktorska. Homburg: Uniwersytet Saarlandzki; 2009. 